\title{
Bioassay of Recombinant Human Granulocyte Colony Stimulating Factor (rhG-CSF) for Neutropenia Treatment in Male Sprague Dawley Rats
}

\author{
Riyona Desvy Pratiwi ${ }^{1}$, Dian Fitria Agustiyanti ${ }^{1}$, Tri Isyani Tungga Dewi ${ }^{2}$, Nina Herlina ${ }^{1}$, \\ Kartika Sari Dewi ${ }^{1}$, Yuliawati ${ }^{1}$, Aminah ${ }^{1}$, Asrul Muhamad Fuad ${ }^{1}$ \\ ${ }^{1}$ Research Center for Biotechnology, Indonesian Institute of Sciences, Bogor, Indonesia \\ ${ }^{2}$ The Veterinary Medical Teaching Hospital, Faculty of Veterinary Medicine, Institut Pertanian Bogor, Bogor, Indonesia
}

Background: Recombinant human granulocyte colony stimulating factor (rhG-CSF) is a first line therapy for neutropenia. However, it is less affordable for most patients in developing and poor countries. Therefore, biosimilar products are developed to suppress the cost of treatment, namely with rhG-CSF. This study aimed to explore the establishment of an affordable rhG-CSF that has similar potential to induce neutrophils recovery as the positive control.

Materials and Methods: The rhG-CSF was expressed as inclusion body in Escherichia coli NiCo21(DE3). The inclusion body was then solubilized, refolded, purified and characterized prior to be used in the bioactivity assay. Cyclophosphamideinduced male Sprague Dawley rats were used as animal model and administered with rhG-CSF. Blood sample was collected at several points of time, before and after rhG-CSF treatments. Complete blood count and peripheral blood smear were conducted to investigate the activity of the rhG-CSF on each blood cells type, particularly neutrophil.

Results: Specific activity on neutrophil proliferation was shown after treatments with our rhG-CSF and positive control. Positive control dose $40 \mathrm{mg} / \mathrm{kg}$ BW was statistically similar with that of the rhG-CSF dose 80 and $120 \mathrm{mg} / \mathrm{kg} \mathrm{BW}$. However, in neutropenic condition, recovery of neutrophil counts could not be achieved within 4 days of treatments. Thus, a longer treatment is needed to observe the activity of the rhG-CSF as an antineutropenia agent.

Conclusion: The rhG-CSF has been proven having specific activity on neutrophil proliferation. However, improvement in the rhG-CSF preparation is still needed and longer administration of the rhG-CSF has to be applied in the future study.

Keywords: rhG-CSF, biosimilar, neutropenia, Sprague Dawley rats

\section{Introduction}

Granulocyte colony stimulating factor (G-CSF) or colony stimulating factor 3 (CSF-3) is a glycoprotein-cytokine with around $20 \mathrm{kDa}$ molecular weight that plays role in hematopoesis control, particularly in neutrophils maturation. ${ }^{1}$ Lacking of G-CSF generates reduction of progenitor cells in bone marrow and spleen. ${ }^{2}$ Chemotherapy administration is

Date of submission: April 2, 2019

Last Revised: May 16, 2019

Accepted for publication: May 20, 2019

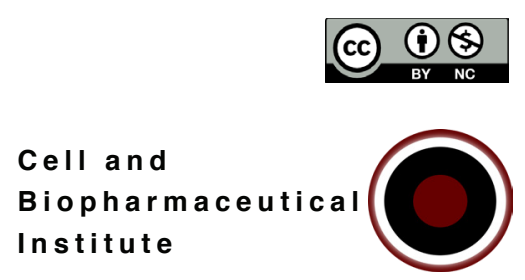

Corresponding Author:

Riyona Desvy Pratiwi

Research Center for Biotechnology,

Indonesian Institute of Sciences,

Jl. Raya Jakarta-Bogor Km 46, Cibinong, Bogor, Indonesia

e-mail: riyona.desvy.pratiwi@lipi.go.id 
known as the main cause the progenitor cells suppression..$^{3-5}$ Neutropenia or condition with neutrophil less than 1500 cells $\mu \mathrm{L}$ is generally found in patients with cancer who received chemotherapy regimen. ${ }^{3}$ Lower neutrophils counts in peripheral blood attenuates immune response, thus patients with neutropenia are vulnerable to infection. In patients with cancer, infection leads to severe complication and increases death risk. ${ }^{3}$ Therefore, synthetic G-CSF is then suggested for patients receiving such chemotherapy treatments. It induces proliferation and differentiation of neutrophils to regain normal counts of neutrophils in the peripheral blood (1500-8000 cells $/ \mu \mathrm{L}){ }^{6,7}$

The synthetic G-CSF or filgrastim or Neupogen which was developed as a recombinant protein and produced in Escherichia coli was approved for clinical used in 1991. ${ }^{8,9}$ It has been used as the first line therapy for chemotherapyinduced neutropenia and proven to be well tolerated by the patients. $^{10}$

Following the patent expiration of Neupogen as the recombinant human G-CSF (rhG-CSF) originator, development of rhG-CSF biosimilar has become interesting for researchers and pharmaceutical industries. The biosimilar products are potential to reduce cost for development and manufacturing, thus they are potentially marketed with almost $50 \%$ lower price than the originator is. ${ }^{11,12}$ A list of rhG-CSF biosimilars has been approved by drug regulator such as European Medicine Agency (EMA), namely Tevagrastim (2008); Ratiograstim (2008); Biograstim (2008); Filgrastim Hexal (2009); Zarzio (2009); Nivestim (2010); Grastofil (2013); and Accofil (2014). ${ }^{13}$

Our group has developed and characterized the synthetic soluble thioredoxin fused-rhG-CSF (Trx-rhG$\mathrm{CSF}$ ) in E. coli expression system. However, purification of rhG-CSF from Trx is high cost and low-yielding. ${ }^{14-17}$ Therefore, in this study, rhG-CSF was expressed as insoluble protein without Trx-fusion and found abundantly in inclusion body agregates which are caused by misfolded protein. The inclusion body was then solubilized and purified to obtain active rhG-CSF. ${ }^{18}$ The active rhG-CSF was evaluated and compared with a commercial rhG-CSF which has been marketed and clinically used in Indonesia.

The activity of our rhG-CSF as antineutropenia agent was investigated using cyclophosphamide induced animal model. Cyclophosphamide is an alkylating agent used as antineoplastic and immunosuppresants. It binds to a DNA strand resulting inhibition of cancer cells proliferation. ${ }^{19,20}$ However, by reason of non-selective action, it is potential to cause a number of adverse effects, such as myelosuppresion, haemorrhagic cystitis, gastrointestinal toxicity, infection, and also includes neutropenia. ${ }^{21,22}$ Therefore, cyclophosphamide was frequently used in preclinical study to develop neutropenic animal model. ${ }^{23-25}$ In the recent study, the induced animal model was treated with the rhG-CSF in various doses and compared with positive control that had been tested in a pre-clinial study. ${ }^{26}$ Complete blood cells analysis was performed to monitor the effect of rhG-CSF on each types of blood cell, particularly on neutrophils. This study aimed to explore whether we could established an affordable rhG-CSF that has similar potential to induce neutrophils recovery as positive control in treating neutropenia, particularly after chemoterapy regimen.

\section{Materials and methods}

\section{Expression, Purification, and Characterization of rhG- CSF}

The rhG-CSF was expressed as inclusion body from an expression vector patented in Patent No. P00201708906 by IPTG induction $0.1 \mathrm{mM}$ (Thermo Scientific, Massachusetts, USA) in Luria Bertani medium which was incubated at $37^{\circ} \mathrm{C}, 150 \mathrm{rpm}$, overnight. ${ }^{27}$ From $100 \mathrm{~mL}$ cells culture, cells pellet was obtained by centrifugating at $6,000 \mathrm{rpm}$ for 6' and then resuspended in phosphate buffer saline enriched with $1 \mathrm{mM}$ phenylmethylsulfonyl fluoride (PMSF). The cells were disrupted by sonification for 5 ' on ice and washed in buffer $\mathrm{pH} 7.9$ containing $20 \mathrm{mM}$ Tris$\mathrm{Cl}, 5 \mathrm{mM}$ ethylenediaminetetraacetic acid (EDTA), 0.5\% Triton-x. Afterwards, the remaining pellet that was known as inclusion body was solubilized and refolded. ${ }^{18}$ Refolded protein was purified using Amicon ${ }^{\circledR}$ Centrifugal filter 10 and 30 molecular weight cut-off (MWCO) (Merckmillipore, Massachusetts, USA). Profiles of solubilized and refolded protein were analyzed with Sodium Dodecyl Sulfate Polyacrylamide Gel Electrophoresis (SDS-PAGE) and characterized with western blot using monoclonal anti-rhGCSF antibody. All other chemical reagents were purchased from Merck (Darmstad, Germany) and Sigma (Santa Cruz, USA).

\section{Preparation of Recombinant Human Granulocyte Colony Stimulating Factor Dosage Form}

The purified rhG-CSF was lyophilized in phosphate buffer saline using a freeze dryer (Alpha 1-4 LDPlus, Christ, Osterode am Harz, Germany). It was immediately 
reconstituted in sterile aquabidest (Ikapharmindo Putramas, Jakarta, Indonesia) before administered in animal model. The positive control, Leukokine (Novell Pharmaceutical Laboratories, Bogor, Indonesia) was reconstituted in 5\% dextrose (Widatra Bhakti, Jakarta, Indonesia) following the manual instruction. Each reconstituted rhG-CSF with different doses, positive control (before reconstituted), and not lyophilized rhG-CSF were analyzed for absorbance and fluorescence spectrum using Varioskan (Thermo Scientific).

\section{Administration of rhG-CSF to Neutropenic Male Rats Sprague Dawley}

The following procedure was approved by Animal Care and Use Committee of Institut Pertanian Bogor - ACUC No. 842017. Healthy male Sprague Dawley rats aged 2-3 months with body weight 200-300 g (Biofarmaka, Institut Pertanian Bogor, Indonesia) were selected and grouped into six groups (six rats per group). Each groups acquired different treatments as follow: Group 1 as normal control which was not received either cyclophosphamide (Endoxan) induction or rhG-CSF treatment; Group 2 as negative control received $5 \%$ dextrose, subcutaneous (s.c); Group 3 as positive control (Leukokine $40 \mu \mathrm{g} / \mathrm{kg} \mathrm{BB}$, s.c); Group 4; 5; and 6 administered with the rhG-CSF 40; 80;120 $\mu \mathrm{g} / \mathrm{kg}$ BW, s.c, respectively. Positive control dose was calculated with dose conversion from human to rat. ${ }^{28}$

The experiment design, specifically in time of induction, treatment, and blood sampling was referred to previous study. ${ }^{23}$ Rats in Group 2-6 were induced with cyclophosphamide $100 \mathrm{mg} / \mathrm{kg} \mathrm{BW}$, intra peritoneally (i.p) at $24 \mathrm{~h}$ after baseline blood sampling (Day -1). The rhGCSF treatments were started at $24 \mathrm{~h}$ after cyclophosphamide induction and continued for 4 days, once per day. Volume administration of cyclophosphamide, dextrose, and rhGCSF was $2.5 \mathrm{~mL} / \mathrm{kg} \mathrm{BW}$. Blood sampling (approximately $0.5 \mathrm{~mL}$ ) was carried out from lateral tail vein on Day 1 and Day 4, $6 \mathrm{~h}$ after treatments on the same day. The rats were sacrificed on the Day 5 by ketamine (Kepro) and xylazin (Interchemie, Netherlands) injection ( $75 \mathrm{mg} / \mathrm{kg} \mathrm{BW}, 8 \mathrm{mg} /$ $\mathrm{kg} \mathrm{BW}$, intramuscular (i.m), $2.5 \mathrm{mg} / \mathrm{kg} \mathrm{BW}$ ). Subsequently, approximately $2-3 \mathrm{~mL}$ of blood was collected from left cardiac vein.

\section{Blood and Organs Analyzes}

Blood samples were analyzed by using hematology analyzer (VetScan HM5, Abaxis, California, USA) for complete blood count and peripheral blood smear with Giemsa staining (Merck). Comparison of each groups at the same sampling time were analyzed by using One Way ANOVA SPSS 16.0 (IBM Corporation, New York, USA), followed by PosHoc Multiple Comparison - Ducan Method with significance level 0.5 .

\section{Results}

\section{Expression, Purification, and Characterization of rhG- CSF}

A significant band was found at size approximately $17 \mathrm{kDa}$ in supernatant after solubilization. As an addition data, remaining pellet after solubilization was also analyzed on SDS-PAGE and showed more abundance of rhG-CSF but containing endogenous contaminant proteins from expression host E.coli NiCo21(DE3) (Figure 1A). In order to obtain rhG-CSF in an active form, the solubilized rhGCSF was refolded and purified. The rhG-CSF which had been prepared in native form was then analyzed with nonreducing PAGE as depicted in Figure 1B. The native form of rhG-CSF was found at approximately $14-15 \mathrm{kDa}$ in size. This non-reducing PAGE was used to confirm that refolded process had been completed. It is shown in Figure 1B lane 2 and 4 in which migration of positive control and refolded protein was similar. As expected, migration of solubilized protein (Figure 1B, lane 3) was slighly faster compared than migration of positive control and refolded protein. However, smear migration was found in the refolded rhGCSF which was not as clean as positive control (Figure 1B). Result of western blotting is shown in Figure 1C. Both of our rhG-CSF and positive control positively bound to the monoclonal anti-rhG-CSF antibody.

As supplementary data, graphs of absorbance and fluorescence spectrum were prepared to access physical similarity of our rhG-CSF and positive control. Those proteins, except not-lyophilized rhG-CSF, have similar absorbance spectrum with optimum wavelenght at approximately $276 \mathrm{~nm}$ (Figure 2A). Moreover, the profiles of fluorescence spectrum of positive control and rhGCSF dose 40; 80; and $120 \mathrm{mg} / \mathrm{kg} \mathrm{BB}$ were also similar, but spectrum of rhG-CSF dose $40 \mathrm{mg} / \mathrm{kg}$ BB had higher intensity (Figure 2B).

\section{Bioactivity Assay of rhG-CSF to Blood Cells Profile of Male Sprague Dawley Rats}

Numbers of each type of blood cell, i.e., leukocytes, platelets, and erythrocytes are represented in the following graphs (Figure 3). Neutrophils, lymphocytes, and monocytes 
A

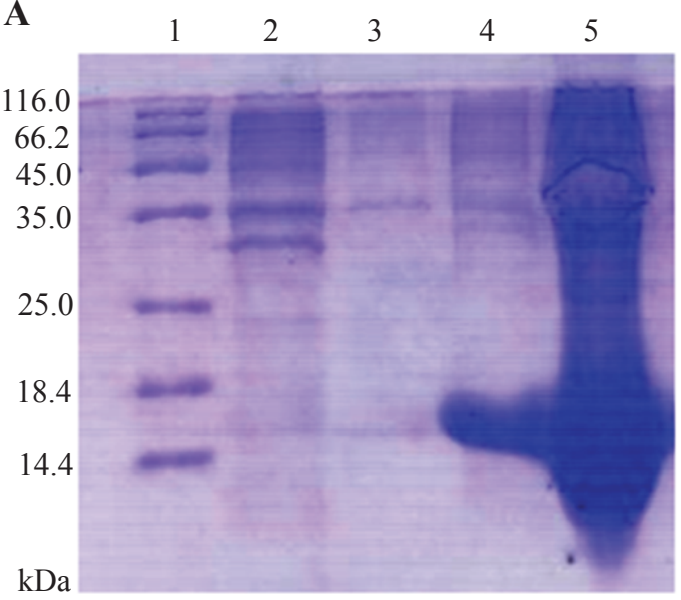

B

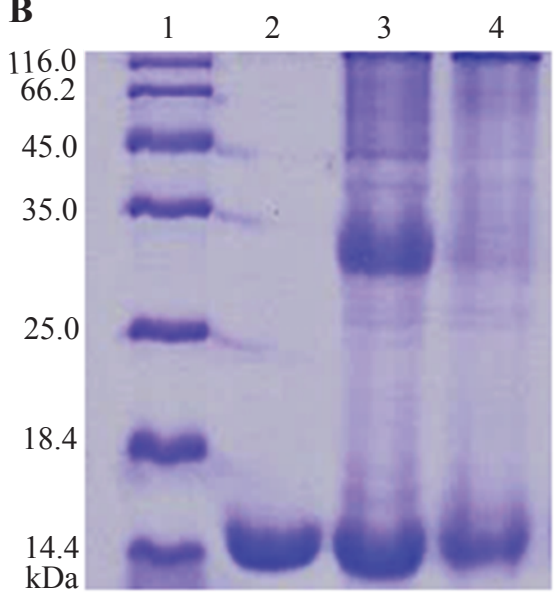

C

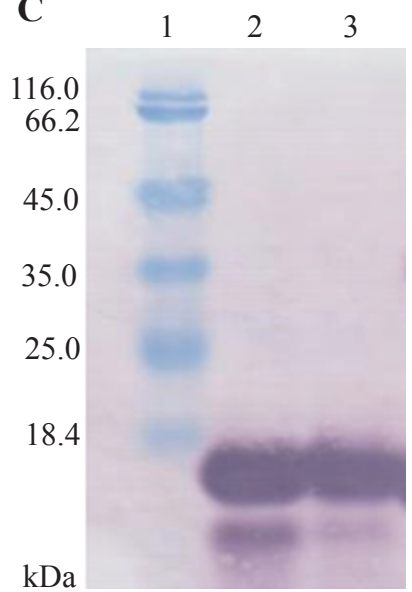

Figure 1. Protein profiles of rhG-CSF. A: SDS PAGE of isolation and solubilization of inclusion bodies, 1) protein marker, 2) supernatant after washing, 3) sitoplasmic protein, 4) supernatant after solubilization, 5) pellet excess of solubilization. B: Non reducing PAGE rhG-CSF, 1) protein marker, 2) Leukokine as positive control, 3) solubilized rhG-CSF or before refolding, 4) refolded rhG-CSF. C: Western blot of rhG-CSF against monoclonal anti rhG-CSF antibody, 1) protein marker, 2) concentrated and refolded rhG-CSF, 3) positive control.

were obtained as percentage in the leukocyte. In Figure 3 , they are represented as cell counts by calculating the percentage towards leukocytes total count. Basophils and eosinophils were found extremely low in rat bloods, thus not detected by the hematology analyzer.

Significant differences were found in leukocytes and neutrophils count on Day 1 in groups treated with positive control; rhG-CSF dose 40 and $80 \mu \mathrm{g} / \mathrm{kg}$ BW compared to normal and negative control group. However, on Day 4 and 5 , no differences of leukocytes and neutrophils count were found among groups. Except leukocytes and neutrophils count, rhG-CSF did not affect other types of blood cell (Figure 3).

Density of blood cells (erythrocytes) were manually observed and found similar among normal, rhG-CSF dose $80 \mu \mathrm{g} / \mathrm{kg} \mathrm{BW}$, and positive control on Day 1. In addition, neutrophils were easily found in rhG-CSF dose $80 \mu \mathrm{g} / \mathrm{kg}$ BW and positive control group. On Day 5, all groups showed reduction in blood cells (erythrocytes) density (Figure 4).

\section{Discussion}

The recent study was initiated by cyclophosphamide administration to gain neutropenic animal model. Likewise other chemotherapy agents, cyclophosphamide induces bone marrow suppression or myelosuppresion causing depletion of blood cells (erythrocytes, leucocytes and platelets) counts. It inhibits proliferation of hematopoetic progenitor cells (HPC), so the degeneration of new blood cells is neglected. Extensive cyclophosphamide exposure does not only impact the HPC, but also perturbs renewal of hematopoietic stem cells (HSC) that causes more severe effects such as bone marrow failure or even death. ${ }^{29,30}$

All types of blood cells (erythrocytes, leukocytes, and platelets) gradually deteriorated by cyclophosphamide induction (Figure 1). On the last day, all of the blood cells parameters were below normal range for male rats aged 2-4 months ${ }^{31}$, whereas the blood cells counts in normal group were relatively steady. However, erythrocytes in normal group were slightly declined that probably due to blood sampling. From the same data, it is known that only neutrophils were affected by rhG-CSF administration. The graph of neutrophil count corresponded with that of leukocytes' one, even though lymphocytes are the most dominant cells in the leukocytes. It indubitably proves that the rhG-CSF specifically acts on neutrophils regeneration, not on other blood cells. This led by G-CSF receptors (G-CSFR) are expressed in neutrophils and their precursors including HSC and HPC. ${ }^{32}$

In our experiment, the administration of rhG-CSF and positive control significantly increased the neutrophils count on Day 2 only. However, at that time point, neutropenic condition was not achieved because the neutrophils count of negative control group was not significantly lower than 

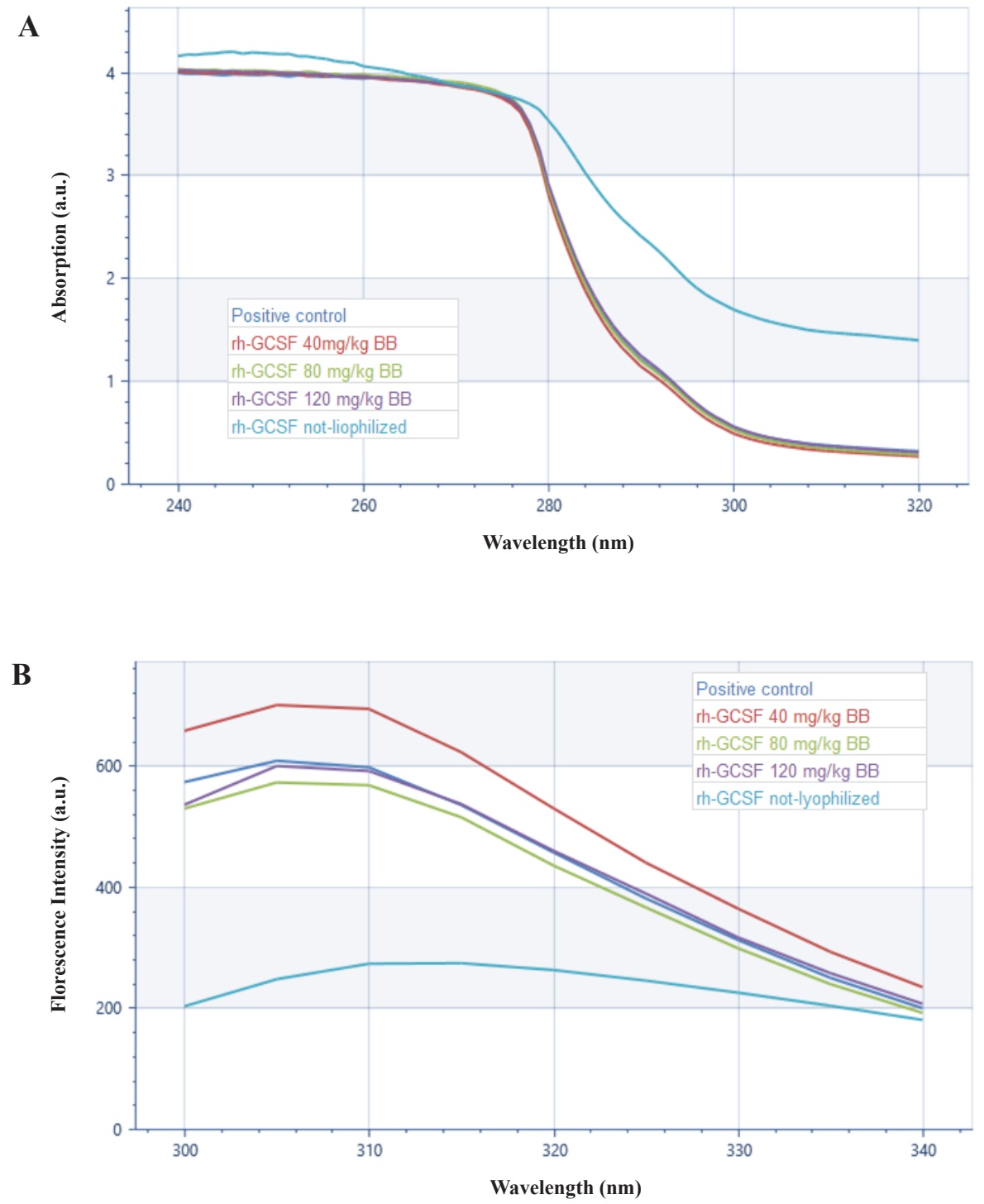

Figure 2. Absorbance and flourescence spectrum of rhGCSF and positive control. A: asbsorbance spectrum; B: fluorescence spectrum of rhGCSF and positive control. that of normal group. It means that either the rhG-CSF or positive control did increase the neutrophils count, but not in neutropenic condition.

Similar effect was found in the rhG-CSF dose $80 ; 120$ $\mathrm{mg} / \mathrm{kg}$; and the positive control $40 \mathrm{mg} / \mathrm{kg}$. This indicates that in order to obtain similar activity in same dose with the positive control, preparation of the obtained rhG-CSF needs to be improved, including dispensing, purification, refolding, and lyophilization.

The refolded rhG-CSF was purified from other contaminants protein, which is dominantly found at approximately $33 \mathrm{kDa}$, by centrifugal filter with $30 \mathrm{kDa}$ cut off and then concentrated by centrifugal filter with $10 \mathrm{kDa}$ cut off (Figure 1B). In order to obtain clean purified rhG$\mathrm{CSF}$ as the positive control, an advanced purification such as size exclusion or ion-exchange chromatrography need to be applied.
In addition, similarity of biological activity of positive control; rh-GCSF dose $80 \mathrm{mg} / \mathrm{kg}$; and $120 \mathrm{mg} / \mathrm{kg}$ was supported by fluorescence spectrum. The fluorescence spectrum of those groups had the same profile and intensity.

Since neutropenia condition did not meet yet on Day 2 , the adminitrastion of rhG-CSF and positive control led over-proliferation of neutrophils counts which reached $>5000$, and considered as neutrophilia (normal neutrophil counts on rat 2-4 months $=220-1570) .{ }^{15}$ Moreover, Welte and Lim performed similar experiment by administrating G-CSF on healthy animal model, also resulting neutrophilia in $4 \mathrm{~h}$ and $24 \mathrm{~h}$ after injection, respectively. ${ }^{26,33}$

Cyclophosphamide started to suppress neutrophil counts on day 3 . Therefore, on the day 3 rats underwent neutropenia $(<220)$ and became severe on day $4(<50){ }^{24}$ However, in the experiment set, neutrophil counts were 

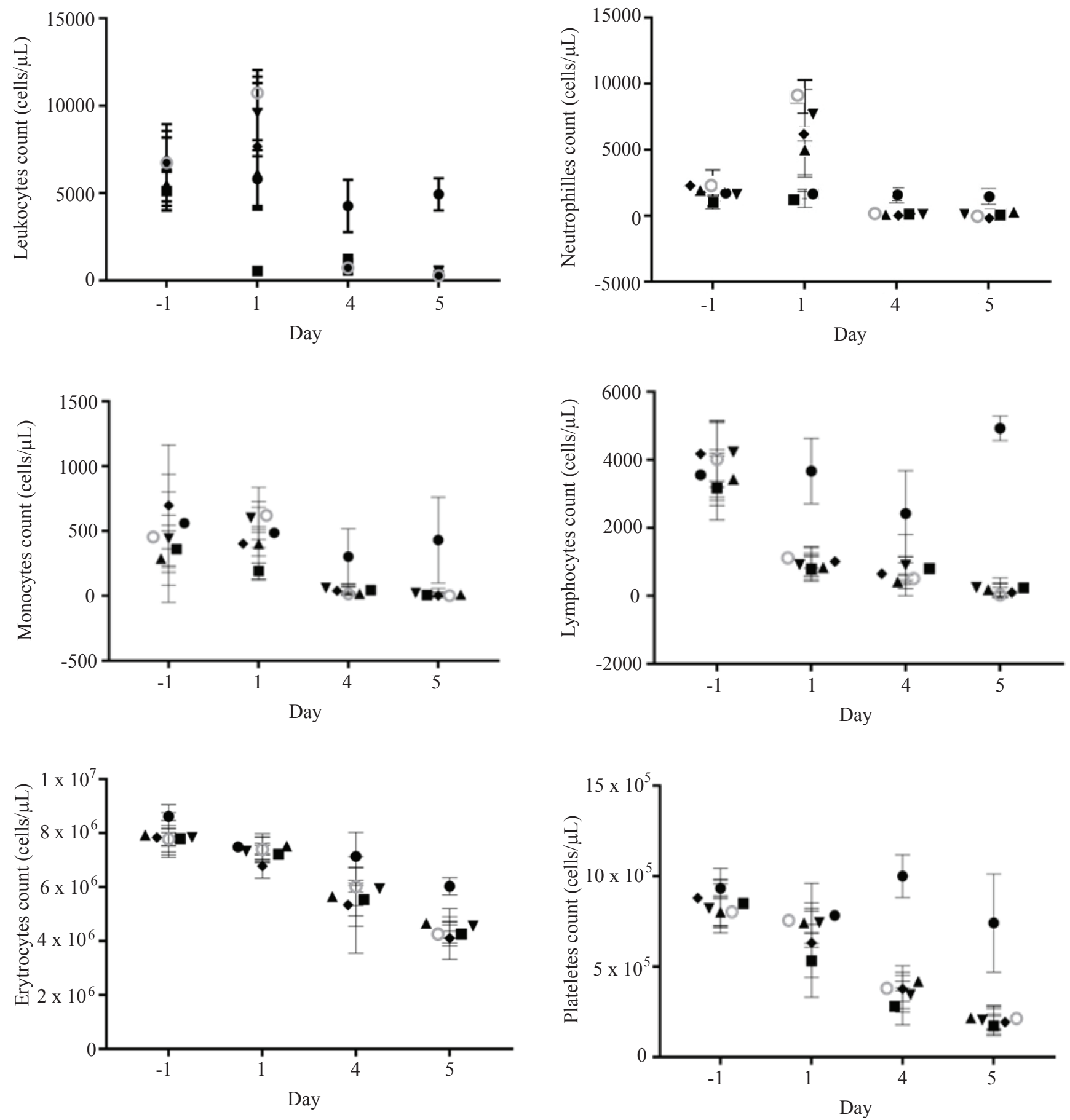

- Normal

- Negative control

- Dose $40 \mu \mathrm{g} / \mathrm{kg} \mathrm{BW}$

- Dose $80 \mu \mathrm{g} / \mathrm{kg} \mathrm{BW}$

- Dose $120 \mu \mathrm{g} / \mathrm{kg} \mathrm{BW}$

- Positive control
Figure 3. Complete blood count of blood sample at Day -1 (baseline or before cyclophosphamide induction), Day 1 (6 h after treatments on Day 1), Day 4(6 h after treatments on Day 4), and Day 5 (30 h after treatments on Day 4). 
not boosted by the rhG-CSF and positive control in the neutropenic condition. In keeping with Welte and colleagues' report, a significant effect of rhG-CSF was observed after 8 days of treatment in cyclophosphamideinduced monkey ${ }^{33}$ The neutrophils that were counted until
34 days remained in normal range after receiving rhG-CSF for 20 days. Therefore, in regards to our experiment, it is assumed that the activity of the rhG-CSF in neutropenia condition needs be observed with longer regimen which is more than 4 days.
Day -1
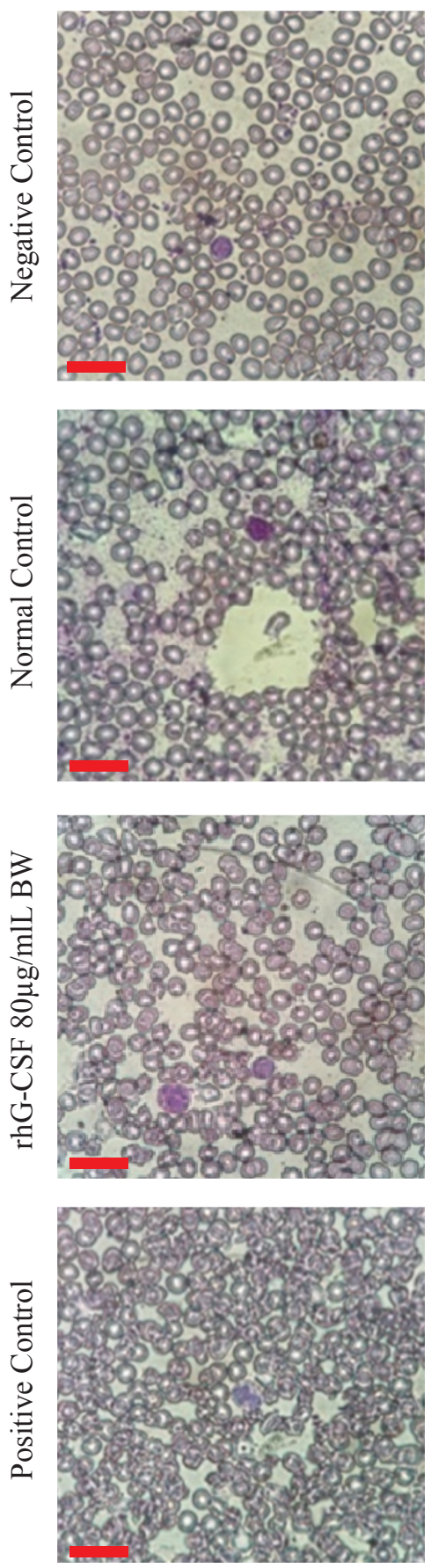

Day 1
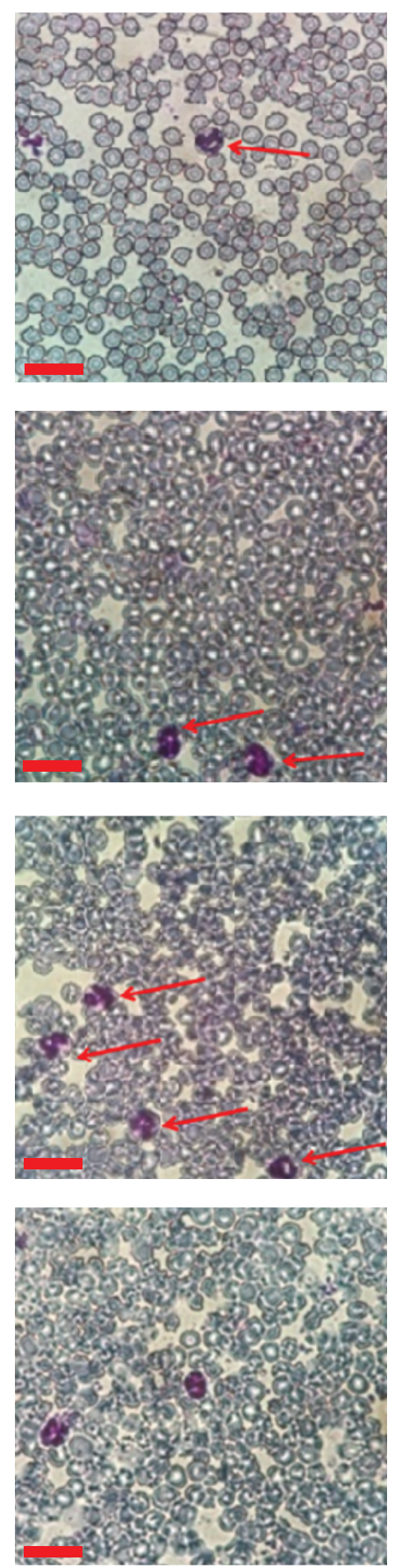

Day 5
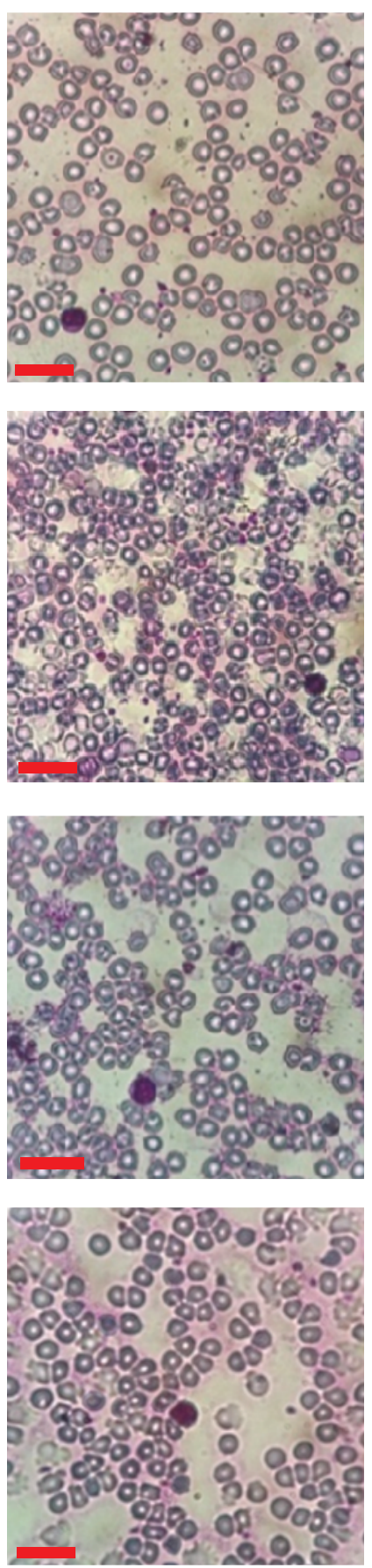

Figure 4. Microscopic visualization of peripheral blood smear, with 100x magnification.

Red bar: $20 \mu \mathrm{m}$. 


\section{Conclusion}

The rhG-CSF that had been produced in our lab showed similar potency in increasing neutropils count in health animals compared with the positive control, but needed 2-3 time higher dose. The effects of both the obtained rhG-CSF and positive control to enhance neutrophils production in neutropenic animal models could not be evaluated in the current study due to short rhG-CSF administration and observation period. Hence, it is suggested that in the further study, the administration of rhG-CSF is requested in longer period of time. In addition, downstream processes of our rhG-CSF have to be improved and more characterzations are required.

\section{Acknowledgements}

Authors would like to thank to all of students who participated in this study: Sabighoh Zanjabilla, Nida Ulfa, Syafira Salsabila, particularly to Denabela Iftina Adibah for documentating blood cells images; Mr. Yuri, paramedic at The Veterinary Medical Teaching Hospital, Faculty of Veterinary Medicine, Institut Pertanian Bogor; and Prof. Dr. Evvy Kartini for her critical reading. This research was financially supported by Kegiatan Unggulan LIPI 2017.

\section{References}

1. Hill CP, Osslund TD, Eisenberg D. The structure of granulocytecolony-stimulating factor and its relationship to other growth factors. Proc Natl Acad Sci. 1993; 90(11): 5167-71.

2. Seymour JF, Lieschke GJ, Grail D, Quilici C, Hodgson G, Dunn AR. Mice lacking both granulocyte colony-stimulating factor (CSF) and granulocyte-macrophage CSF have impaired reproductive capacity, perturbed neonatal granulopoiesis, lung disease, amyloidosis, and reduced long-term survival. Blood. 1997; 90(8): 3037-49.

3. Crawford J, Dale DC, Lyman GH. Chemotherapy-induced neutropenia: risks, consequences, and new directions for its management. Cancer. 2004; 100(2): 228-37.

4. Nurgalieva Z, Liu CC, Du XL. Chemotherapy use and risk of bone marrow suppression in a large population-based cohort of older women with breast and ovarian cancer. Med Oncol. 2011; 28(3): 716-25.

5. Aslam MS, Naveed S, Ahmed A, Abbas Z, Gull I, Athar MA. Side effects of chemotherapy in cancer patients and evaluation of patients opinion about starvation based differential chemotherapy. J Cancer Ther. 2014; 5(8): 817-22.

6. Lustberg MB. Management of neutropenia in cancer patients. Clin Adv Hematol Oncol. 2012; 10(12): 825-6.

7. Mayordono JI, Rivera F, Diaz-Puente MT, Lianes P, Colomer R, Lopez-brea E, Paz-Ares L, Hitt R, Garcia-Rbas I CR. Improving treatment of chemotherapy-induced neutropenic fever by administration of colony-stimulating factors. J Natl Cancer Inst. 1995; 87(11): 803-8.
8. Lieschke G, Grail D, Hodgson G, Metcalf D, Stanley E, Cheers C, et al. Mice lacking granulocyte colony-stimulating factor have chronic neutropenia, granulocyte and macrophage progenitor cell deficiency, and impaired neutrophil mobilization. Blood. 1994; 84(6): 1737-46.

9. Neuman TA, Foote M. The safety profile of filgrastim and pegfilgrastim. In: Graham Molineux, MaryAnn Foote TA, editor. Twenty Years of G-CSF. Berlin: Springer Science \& Business Media; 2012. p.395-408.

10. Advani S, Achreckar S, Thomas D, Krishnankutty B. Granulocyte colony-stimulating factor (filgrastim) in chemotherapy-induced febrile neutropenia. Indian J Med Paediatr Oncol. 2010; 31(3): 7982.

11. Blackstone EA, Fuhr JP. The economics of biosimilars. Am Heal Drug Benefits. 2013; 6(8): 469-77.

12. Mulcahy AW, Hlavka JP, Case SR. Biosimilar Cost Savings in the United States: Initial Experience and Future Potential. Perspectives (Montclair). California: Rand Corporation; 2017.

13. Zielinska J, Bialik W. Recent changes on the biopharmaceutical market after the introduction of biosimilar G-CSF products. Oncol Clin Pract. 2016; 12(4): 144-52.

14. Agustiyanti DF, Retnoningrum DS, Rachmawati H, Fuad AM. Overproduction and purification of soluble recombinant human granuocyte colony stimulating factor in Escherichia coli using thioredoxin as fusion. Annales Bogorienses. 2017; 21(1): 1-8.

15. Pratiwi RD, Fuad AM. Soluble expression of synthetic CSF3syn gene fused with thioredoxin in Escherichia coli BL21(DE3) through autoinduction method and purification. Res Artic Vol Indones J Pharm. 2015; 26(2): 63-70.

16. Agustiyanti DF, Pratiwi RD, Fuad AM. Pengaruh konsentrasi imidazol pada proses pemurnian protein rekombinan hG-CSF (human granulocyte-colony stimulating factor). Pros Semin Nas Biol 2014 Biol Penelitian, Pengembangan, dan Pembelajarannya Jur Biol Fak Mat dan Ilmu Pengetah Alam Univ Negeri Semarang Maret. 2015; 2015: 240-5.

17. Pratiwi RD, Fuad AM. Influence of temperature on recombinant granulocyte colony stimulating factor autoinduced production by Escherichia coli BL21(DE3) expression system. Proceding Int Conf Biotechnol 2012 Biotechnol Biodivers to Ind Res Cent Biotechnol Indones Inst Sci. 2013; 2013: 419-28.

18. Kim CK, Lee CH, Lee SB, Oh JW. Simplified large-scale refolding, purification, and characterization of recombinant human granulocyte-colony stimuating factor in Escherichia coli. PLoS ONE. 2013: 8(11): e80109. doi: 10.1371/journal.pone.008109.

19. Johnson LA, Malayappan B TN. Formation of cyclophosphamide specific DNA adducts in hematological diseases. Pediatr Blood Cancer. 2012; 58(5): 708-14.

20. Alyamkina EA, Nikolin VP, Popova NA, Minkevich AM, Kozel AV, Dolgova E V, et al. Combination of cyclophosphamide and doublestranded DNA demonstrates synergistic toxicity against established xenografts. Cancer Cell Int. 2015; 15(1): 1-14.

21. Martin F, Lauwerys B, Lefebvre C, Devogelaer JP, Houssiau FA. Side-effects of intravenous cyclophosphamide pulse therapy. Review. 1997; 6(3): 254-7.

22. McKeon C. Reducing the side effects of chemotherapy. Aust Nurs J. 2012; 19(8): 41.

23. Hattori K, Shimizu K, Takahashi M, Tamura M, Oheda M, Ohsawa $\mathrm{N}$, et al. Quantitative in vivo assay of human granulocyte colonystimulating factor using cyclophosphamide-induced neutropenic mice. Blood. 1990; 75(6): 1228-33. 
24. Zuluaga F, Jones LM. Protecting indigenous rights in Colombia. Peace Rev. 2006; 18(1): 55-61.

25. Morley A, Stohlman F. Cyclophosphamide-induced cyclical neutropenia. N Engl J Med. 1970; 282(12): 643-6.

26. Lim DM. The effect of single administration of rG-CSF on the peripheral neutrophil levels and its dose responsiveness in normal ICR mice and SD rats. J App Pharmacol. 1997; 5: 380-3.

27. Sari DK, Fuad AM, Yuliawati, Agustiyanti DF, Pratiwi RD. Proses Pembuatan Protein Rekombinan Human Granulocyte-Colony Stimulating Factor (rH-GCSF) Dalam Bentuk Badan Inklusi Menggunakan Bakteri Escherichia coli. Paten No. P00201708906. Bogor: LIPI; 2017.

28. Laurence AL. Bacharach: Evaluation of Drug Activities. 1st Ed. Massachusetts: Academic Press; 1964.
29. Feng L, Huang Q, Huang Z, Li H, Qi X, Wang Y, et al. Optimized animal model of cyclophosphamide-induced bone marrow suppression. Basic Clin Pharmacol Toxicol. 2016; 119(5): 428-35.

30. Wang Y, Probin V, Zhou D. Cancer therapy-induced residual bone marrow injury-Mechanisms of induction and implication for therapy. Curr Cancer Ther Rev. 2006; 2(3): 271-9.

31. Giknis MLA, Clifford CB. Clinical Laboratory Parameters for Crl:WI(Han). Wilmington: Charles River; 2008.

32. Roberts AW. G-CSF: A key regulator of neutrophil production, but that's not all! Growth Factors. 2005; 23(1): 33-41.

33. Welte K, Bonilla MA, Gillio AP, Boone TC, Potter GK, Gabrilove JL, et al. Recombinant human granulocyte colony-stimulating factor. Effects on hematopoiesis in normal and cyclophosphamide-treated primates. J Exp Med. 1987; 165(4): 941-8. 